\title{
Cortegpondente.
}

"Audi alteram partem."

\section{MEMORIAL STATUE TO SIR THOMAS BROWNE, M.D.}

To the Editors of THW LANCET.

SIRS,-The committee begs permission to appeal throngh your columns for the support of the medical profession to the above memorial. Sir Thomas Browne in his day occupied the highest position in h's profession and is confessedly one of the greatest and most eminent of our English writers and philosophers. Yet he stands almost alone amongst these as having no permanent public memorial. The movement to erect a statue of him in Norwich, where he resided for 46 years and where he is buried, has received most influential support both medical and general, and it now includes that of the Royal College of Physicians of London and of its President. The sum of about $\$ 400$ has so far been subscribed and further contributions are now solicited towards the estimated $£ 1000$ or $£ 1200$ required. Donations to the fund will be gladly received by either of the honorary secretaries, Dr. Bensly or Mr. Charles Williams of Norwich, or by the acting secretary, Mr. F. R. Eaton, King-street, Norwich. I am, Sirs, yours faithfully,

PeTER EAde

May 24th, 1899. Chairman of Committee

\section{PERSONATION BY "QUALIFIED" ASSISTANTS.}

\section{To the Editors of THE LANCET.}

SIRs,-Will you allow me space to caution medical practitioners against employing alleged qualified assistants unti those seeking employment can produce certificates of registration from the General Medical Council and diplomas. There are cases of undoubted personation in existence nowunqualified men taking and using the names of duly qualified practitioners without, I need hardly say, the krowledge and consent of the latter. I have just come across such a case, the third within a short space of time and I trust that steps may be taken to prosecute the offender.

I am, Sirs, yours faithfully,

\section{A. G. BATEMAN,}

4, Trafalgar-square, W.c.

General Secretary of the Defence Union.

\section{THE OPEN-AIR TREATMENT OF PHTHISIS IN VICTORIA.}

To the Editors of THE LANCET.

SIRS,-In an abstract from Dr. McAdam's presidential address at the annual meeting of the Victorian Branch of the British Medical Association which appeared in THE LANCET of Feb. 11th is the following sentence: "That while the Tictorian climate was 'second to none in the facilities it afforded for taking advantage of the full benefit of the open-air treatment, yet there was in the colony no institution in which any attempt was made to carry it out in its completeness." "Now so far from this being the case we have in Victoria two buildings known conjointly as the Victorian Sanatorium for Consumptives-one on the dry plains for winter and a mountain retreat for the hot months. Altogether there are 54 beds which are under one management and are generally full. It is difficult to know what Dr. McAdam means by the open-air treatment "in its completeness," for even in Germany, the cradle of the system, the treatment varies in different sanatoria. Our institution is carried on medically and financially much on the same lines as Ruppertshain in Germany and Heiligenschwendi in Switzerland, which were recently visited by myself. In another part of the colony there is in connexion with the Austin Hospital for Incurables accommodation for 30 incurable cases. This institution works in a friendly way with the Victorian Sanatorium and patients are frequently interchanged. Considering that the population of our colony is only a little over a million I think that as far as accommodation for consumptives is concerned we compare favourably with other places. I may say that I am rather surprised that a gentleman of Dr. McAdam's standing should make such a statement without duly acquainting himself with the facts.

I am, Sirs, yours faithfully,

DUNCAN TURner, M.R.C.P. Lond.,

April 8th, 1899

Honorary Medical Examiner, Victorian Sanatorium.

\section{"FEES TO MEDICAL WITNESSES AT ASSIZES AND SESSIONS." \\ To the Editors of THE LANCET.}

SIRS,-Let me thank you for once more bringing this matter to the front. I wonder how many medical men will have the courage to act upon the suggestion which you throw out in the last paragraph of the leading article under the above heading in THE LANCET of May 6th. I do not object to the medical men here refusing to make the sacrifices entailed by accepting police and assize court work. They do it though with the knowledge that the police surgeon is not quite so free as themselves to refuse all the filthy cases. The matter of the rape which you allude to seems like one that happened here a month ago when for more than two hours the police vainly tried to induce a medical man to examine an unfortunate child, 10 years old, who was said to have been criminally assaulted. It seems that it will take a few scandalous cases of that kind to bring the Home Secretary to understand that we are in earnest. I would suggest that all medical men should communicate with their respective Members of Parliament with a view to bringing some pressure to bear upon the Home Office. I am, Sirs, yours faithfully,

Hindley, May 15th, 1899

J. CHRONNELL.

\section{COINCIDENCES IN MEDICAL PRACTICE. To the Editors of THH LANOET.}

SiRs,-In The LANCET of May 13th you comment on this point under the heading "Coincidences in Hospital Practice," the annotation being suggested by articles on two rare forms of hernia and two cases of filariasis which had come under observation at the London Hospital witbin a very short space of time. As you remark, cases such as these are by no means uncommon in hospital practice, but they are far less frequently seen in private practice, and it is this fact of "coincidence" alone and not the nature of the injury sustained which induces me to place on record the following singular experience.

About noon on Sunday, April 30th, 1899, a man from Tillingham (a village 16 miles away), aged 68 years, was admitted to the Maldon Workhouse Infirmary under the care of my partner, Mr. Thomas Tomlinson, the medical officer, suffering from an injury to the left shoulder. He stated that he was at Bradwell, a village near Tillingham, on the previous Thursday evening, April $27 \mathrm{th}$, and whilst holding a horse harnessed to a trap the animal reared, lifting him suddenly from the ground by the left arm. A medical man found that the patient had sustained a dislocation of the humerus, but he could not reduce it at the time or at a second attempt made on April 29th. The patient was therefore sent to the workhouse infirmary. We found the injury to be of the subglenoid variety, and under anæsthetics reduction was effected. The patient returned to his home on the same afternoon.

On the following day at 1 P.M. a native of Bradwell, aged 19 years, was admitted to the workhouse infirmary suffering from an injury to the left shoulder received at the same time as the injury to the previous patient had been received. The history he gave was that when the former patient fell to the ground he had gone to his assistance and was knocked down by the horse, his left arm being trampled upon. We diagnosed a sub-glenoid disloçation and under slight anæsthesia this was quickly reduced, although owing to the patient being rather muscular more force was required than in the first case. He left the workhouse almost immediately. That as the result of what may be called one accident two persons only should suffer and each receive exactly the same injuryviz., a dislocation on the same side and of the same varietyand that injury alone, must $I$ think be a unique occurrence. The accuracy of the patients' statements was vouched for by the gentleman who brought them both to the workhouse. I am, Sirs, yours faitbfully,

Maldon, Essex, May 23rd, 1899
HENRY J. PrICE, F.R.C.S. Eng。 